\title{
Modelling overland flow on burned hillslopes using the KINEROS2 model
}

\author{
L.P. Kasmaei $^{\text {a }}$, R. Van Der Sant, P.J. Lane ${ }^{\text {a }}$ and G. Sheridan ${ }^{\text {a }}$ \\ School of Ecosystem and Forest Sciences (SEFS), Faculty of Science \\ The University of Melbourne \\ Email: lpourfathali@student.unimelb.edu.au
}

\begin{abstract}
A process-based study was conducted to investigate soil infiltration and overland flow dynamics in response to post-fire soil-surface characteristics on a dry burned hillslope one year following wildfire. The study consists of analysing data from paired rainfall-runoff plots, field and laboratory measurements, and plot-scale simulations of overland flow using the KINEROS2 rainfall-runoff model.
\end{abstract}

Post-fire soil-surface characteristics and rainfall data were collected from paired rainfall-runoff plots located in dry eucalyptus forest, southeast Australia, severely burned by wildfire in January 2013.

Field and laboratory measurements were undertaken on six separate occasions during the study period and confirmed the existence of strong hydrophobicity within $4 \mathrm{~cm}$ soil depth, restricting vertical infiltration and increasing the rate of runoff, although with a declining trend with time since fire. The strength of hydrophobicity steadily weakened from depth $4 \mathrm{~cm}$ downward, becoming non-repellent below $8 \mathrm{~cm}$.

Event-based simulations of soil infiltration and surface runoff were implemented using the KINEROS2 model for fourteen rainfall events. Spatial factors representing post-fire soil-surface conditions were calibrated with highly acceptable model efficiencies for the majority of the events. Simulated hydrographs were validated against observed data from runoff plots. The key properties impacting dynamics of simulated hydrographs were identified as soil hydraulic conductivity $\left(\mathrm{K}_{\mathrm{sat}}\right)$, net capillary drive $(\mathrm{G})$ and surface roughness respectively. The existence and breakage of fire-induced water repellency was simulated by appointing variable values for effective hydraulic conductivity.

Parameterized values of soil saturated hydraulic conductivity $\left(\mathrm{K}_{\mathrm{sat}}\right)$ showed that the existence and breakage of fire-induced water repellency during the first year following fire did not follow seasonal oscillations of natural water repellency. The calibrated effective hydraulic conductivity was in the range of $2-4 \mathrm{~mm} / \mathrm{h}$ during the first winter following fire, reflecting strong water repellency. Fire-induced water repellency broke down during the early autumn next year and soil hydraulic conductivity increased suddenly to $\left(\mathrm{K}_{\text {sat }}>10 \mathrm{~m} / \mathrm{h}\right)$. A constant value of $2 \mathrm{~mm}$ was parametrized with the factor of 0.1 for the net capillary drive $(\mathrm{G})$ parameter. The capillary depression could be result of large contact angle $\left(>90^{\circ}\right)$ between liquid-solid interface in water repellent soil.

Hydraulic roughness was represented by Manning's n coefficients and simulated hydrographs with higher roughness values obtained lower errors in peak and mean values. The theoretical primary roughness factor that only included bed size particles $\left(0.085 \mathrm{sm}^{-1 / 3}\right)$ was re-calibrated by the factor of seven after calibration $\left(0.64 \mathrm{sm}^{-1 / 3}\right)$. Similar trend of higher values for Manning's $n$ was also reported by Chen et al. (2013) who used Kineros 2 for modelling rainfall-runoff in fire affected watersheds.

Dynamics of simulated hydrographs were found less sensitive to variations of the second group of soil hydraulic properties (porosity, pore index and initial water content), $<5 \%$ variations in model efficiencies and error indicators.

The soil infiltration model in KINEROS2 was well-adjusted to fire-induced hydrophobic soil by adapting infiltration concepts and domains to measurements and observation of post-fire soil-surface conditions in the initial model setup and parametrization $(\mathrm{ME}>50 \%$ and $\mathrm{R} 2>0.5)$. The model successfully simulated dominant factors in controlling vertical preferential water movement and their trend change during post-fire recovery period.

Keywords: Soil water repellency, overland flow, modelling, KINEROS2, infiltration 


\section{INTRODUCTION}

The enhancement of overland flow from storm events following wildfire has been widely reported e.g. 1.5 to 3 -fold increase in burned eucalyptus forest, Southeast Australia (Sheridan et al., 2007), 4-fold more overland flow in burned pine forest, California (Onda et al., 2008).

Depending on burn severity and landscape geomorphic conditions, watersheds may respond to this excessive overland flow with flooding, upstream erosion, debris flows and downstream sedimentation. Increased sediment (and nutrients) in water bodies may have consequences for aquatic ecosystem health and drinking water operation utilities (Smith et al., 2011), while post-fire flooding and debris flows can threaten human lives and destroy infrastructure (Nyman et al., 2011).

Fire-induced changes in that impact on overland flow hydraulics are soil properties alterations (Moody et al., 2013), fire-induced water repellency (Sheridan et al., 2007; Doerr et al., 2009) and macro-pore infiltration (Nyman et al., 2010). Reduction in surface roughness (Stoof et al., 2012), and higher portion of bare soil patches (Cawson et al., 2012) are other fire-induced spatial alterations that impact both runoff generation and its connectivity.

The lack of knowledge in understanding of the key processes and factors affecting post-fire hydrogeomorphology results in uncertainties associated with predictions of extreme events following fire. The result of this process-based study could help obtaining predictions close to real events by drawing the main focus on important factors while less influential variables could be ignored to decrease the system complexity.

The objectives in this study are: 1) Undertake plot-scale simulations of event-based rainfall-runoff processes by modifying soil-surface spatial parameters to post-fire conditions and their gradual recovery during the first year following wildfire, 2) Categorizing dominant soil-surface spatial factors based on their influence in governing volumetric and temporal dynamics of overland flow in burned dry eucalyptus.

\section{STUDY SITE}

The study site is located in dry eucalyptus forest severely burned on January 2013 for approximately six weeks to a total size of 86,000 ha (DEPI, 2014), between Aberfeldy $\left(37^{\circ} 41^{\prime} \mathrm{S} 146^{\circ} 22^{\prime} \mathrm{E}\right)$ and Walhalla $\left(37^{\circ} 56^{\prime} \mathrm{S}\right.$ $146^{\circ} 27^{\prime} \mathrm{E}$ ), Victoria, Australia. The forest abuts the Thompson River dam to the west, part of Melbourne's water supply catchments.

An instrumented monitoring site was established on a north-facing steep hillslope within the fire area $\left(37^{\circ} 45^{\prime} 36.9^{\prime \prime} \mathrm{E}, 146^{\circ} 25^{\prime}\right.$ $9.27^{\prime \prime} \mathrm{N}$ ) with the elevation of $832 \mathrm{~m}$ above sea level. A rainfall throughfall gutter; collecting rainfall at the level of the ground surface, and two $8 \times 1.5 \mathrm{~m}$ bounded runoff plots were operational at the site from June 2013 to April 2014. Each plot was connected to a $0.5 \mathrm{~L}$ tipping bucket and data from these buckets was recorded every three minutes to a data logger.

Observations of soil-surface after the wildfire showed that a layer of high density burned residue containing of burned organic matter, charcoal, black carbon with an average depth of $20 \mathrm{~mm}$ remained on the soil surface creating a two-layer system of burned material on top and mineral soil under beneath.

The burned woody layer and the mineral soil underneath were found to have different hydrologic characteristics and hydraulic

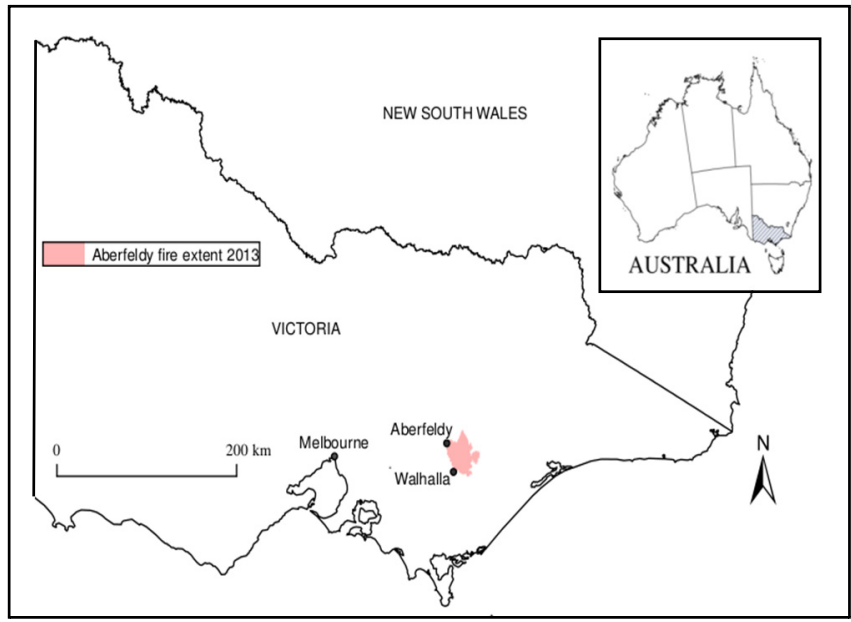

Figure 1. Map showing location and extent of the Aberfeldy 2013 fire.

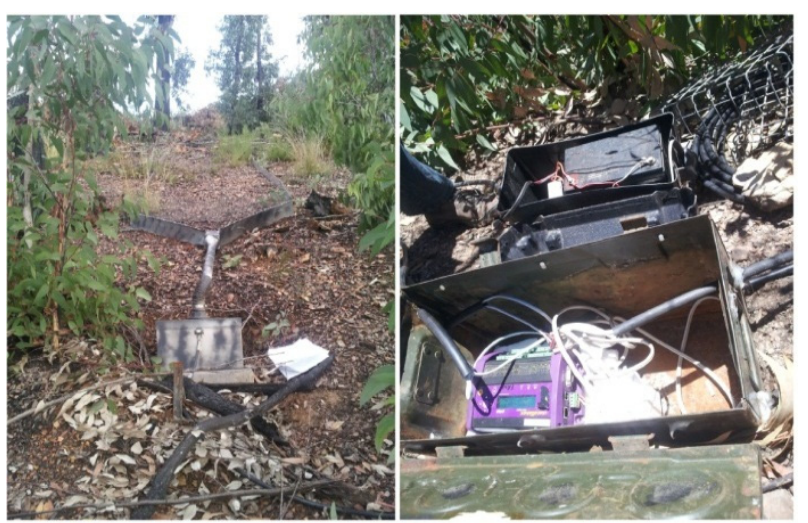

Figure 2. Runoff plot and its tipping bucket (left) and data logger collecting data every three minutes (right). 
conductivity that resulted in considerable variability in infiltration rate within depth. The

organic layer was highly wettable with a relatively large water storage capacity; $2 \mathrm{~mm}$ per $2 \mathrm{~cm}$ depth, while deeper penetration was limited due to fire-induced water repellency of mineral soil downward, giving a low range of $\mathrm{K}_{\mathrm{sat}}$ within $10 \mathrm{~cm}$ depth.

The intense rain following fire could easily infiltrate into the burned organic layer and stored water in this layer might turn either into saturated overland flow or infiltrates downward through preferential flow paths (Nyman et al., 2010, 2014).

Soil properties at the site were sampled to a depth of $10 \mathrm{~cm}$ along transects adjacent to runoff plots during Nov-Dec 2013 to determine soil texture, porosity, bulk density, air dry/background water repellency and saturated hydraulic conductivity.

Measurements of soil water repellency and water content were undertaken under field condition on six separate occasions, from early October 2013 to

Table 1. Study site soil properties to a depth of $10 \mathrm{~cm}$.

\begin{tabular}{|c|c|c|}
\hline Soil property & Measurement method & Result \\
\hline \multirow{2}{*}{$\begin{array}{l}\text { Saturated hydraulic } \\
\text { conductivity }\left(\mathrm{K}_{\text {sat }}\right)\end{array}$} & Tension infltrometer & $39.5 \mathrm{~mm} / \mathrm{h}(\mathrm{SD} 30.8)$ \\
\hline & ponded infltrometer & $74.1 \mathrm{~mm} / \mathrm{h}(\mathrm{SD} 40.4, \mathrm{n}=2)$ \\
\hline \multirow{2}{*}{$\begin{array}{l}\text { Soil texture and } \\
\text { particle size (\%) }\end{array}$} & $\begin{array}{l}\text { Sieving and particle } \\
\text { size analyzer }\end{array}$ & $\begin{array}{l}15 \% \text { Clay, } 44 \% \text { Silt, } 41 \% \text { Sand } \\
\text { Course fraction }(>2 \mathrm{~mm}) 45 \%\end{array}$ \\
\hline & Texture triangle class & Silty loam \\
\hline Porosity & Tension table & $\begin{array}{l}38.5 \%(\mathrm{SD} 0.04, \mathrm{n}=3) \\
\text { corrected for gravel (porosity } \\
\text { of }<2 \mathrm{~mm} \text { fraction) }\end{array}$ \\
\hline Soil Water Content & Oven drying & Average $5.1 \%$ (SD 3.8, n 52) \\
\hline $\begin{array}{l}\text { Potential Soil Water } \\
\text { Repellency }\end{array}$ & $\begin{array}{l}\text { Critical Surface } \\
\text { Tension }\end{array}$ & $\begin{array}{l}\text { Average Air dry CST } \\
60.3 \mathrm{mN} / \mathrm{m}^{2}(\mathrm{SD} 13.0, \mathrm{n} 24)\end{array}$ \\
\hline \multirow{2}{*}{$\begin{array}{l}\text { Bulk density } \\
\left(\mathrm{g} / \mathrm{cm}^{3}\right)\end{array}$} & Total & $1.19(\mathrm{SD} 0.08, \mathrm{n} 9)$ \\
\hline & $\begin{array}{l}\text { Fine fraction }(<2 \mathrm{~mm}) \\
\text { (gravel corrected) }\end{array}$ & $0.86(\mathrm{SD} 0.46, \mathrm{n} 9)$ \\
\hline
\end{tabular}

*SD: Standard deviation, CST: Critical Surface Tension (mN/m2)

March 2014. Soil moisture samples were divided by depth into surface $(0-2 \mathrm{~cm})$ and sub-surface $(8-10 \mathrm{~cm})$. Samples were weighed, oven dried at $105^{\circ} \mathrm{C}$ for 24 hours, and reweighted to obtain the percentage of gravimetric water content (GWC) as presented in Figure 3b. To study soil water repellency, both field and laboratory measurements were completed in this study. Measurements at the field were in situ at $1 \mathrm{~cm}$ depth intervals from $0-10 \mathrm{~cm}$ along a small trench or wedge similar to the method outlined in Nyman et al. (2010). Critical surface tension (CST) was calculated from both the water drop penetration test and $2 \mathrm{M}$ ethanol test (Letey, 2000) in $1 \mathrm{~cm}$ depth increments.

Laboratory measurements were undertaken on air dried soil samples $(2-4 \%$ GWC), collected across transects for soil properties analysis. Soil water repellency patterns as a function of soil depth, and average and proportions of repellent and non-repellent soil were obtained from late winter following fire to the end of summer (Figure $3 \mathrm{a} \& \mathrm{~b}$ ).
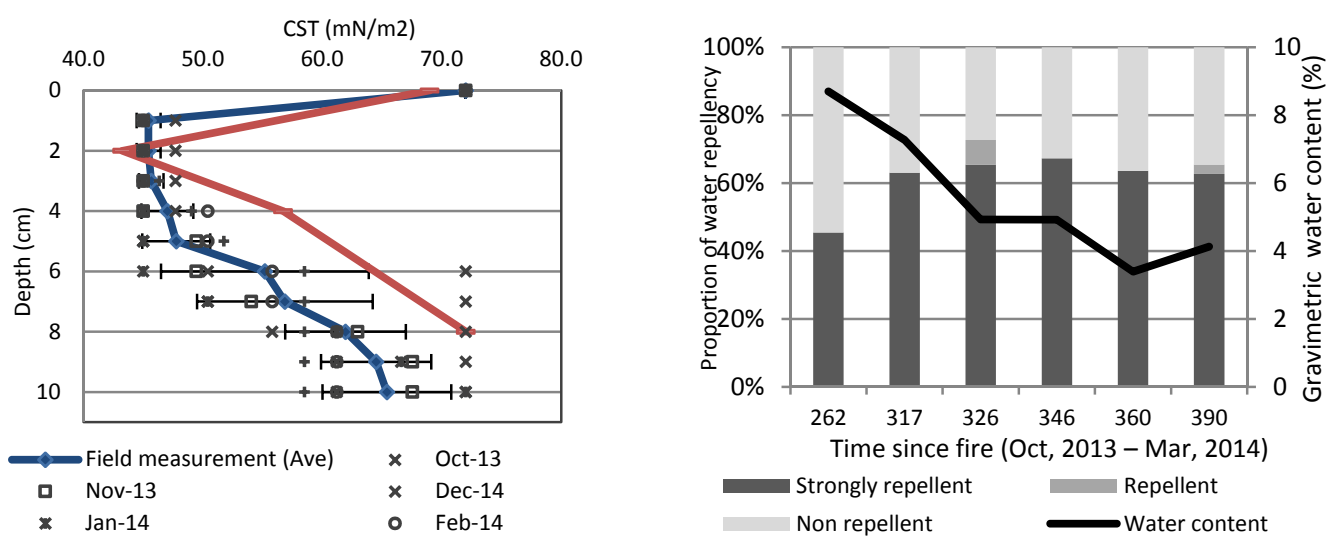

Figure 3. a) Changes in water repellence strength in depth b) Proportional of water repellence strength and gravimetric soil water content. Corresponding CST values for water repellency categories; Non repellent $>72 \mathrm{mN} / \mathrm{m} 2$, Repellent $72-45 \mathrm{mN} / \mathrm{m} 2$, Strongly Repellent $<45 \mathrm{mN} / \mathrm{m} 2$.

\section{MODELLING}

The event-based physically-oriented rainfall-runoff model, KINEROS2 (Smith et al., 2005) was used to simulate infiltration-excess overland flow dynamics on two $8 \times 1.5 \mathrm{~m}$ planes individually. The primary soil infiltration model in KINEROS was set based on infiltration equations of Parlange et al. (1982) with four basic parameters representing soil infiltration properties: effective saturated hydraulic conductivity $\left(\mathrm{K}_{\mathrm{sat}}\right)$; 
effective net capillary drive $(\mathrm{G})$ derived from soil texture class; initial soil moisture, and soil porosity $(\Phi)$. Another parameter; pore size distribution index $(\lambda)$ was added later to the next version (KINEROS2) from the statistical study of soils texture by Rawls et al. (1982) affecting water retention calculations.

\subsection{Initial Model Setup}

Due to strong water repellency, shallow soil profile, and the absence of base flow in the study area, only infiltration-excess flow which is the dominant flow type in burned dry forest (Sheridan et al., 2007; Lane et al., 2012; Moody et al., 2013), was considered in rainfall-runoff model.

In severely burned conditions, only the skeleton of trees remained and hence no interception storage was considered for canopies and shrubs. Distinctly varied hydraulic characteristics of the burned organic layer on top and water repellent mineral soil underneath resulted in a sudden shift in the rate of infiltration at the depth of $20 \mathrm{~mm}$ in the soil profile. For this reason, a surface interception compartment with $2 \mathrm{~mm}$ abstraction was considered for the burned organic layer before infiltration process taking place in water repellent soil underneath.

To adjust the infiltration model with the fire-induced water repellent soil in the study area, a two-layer system was

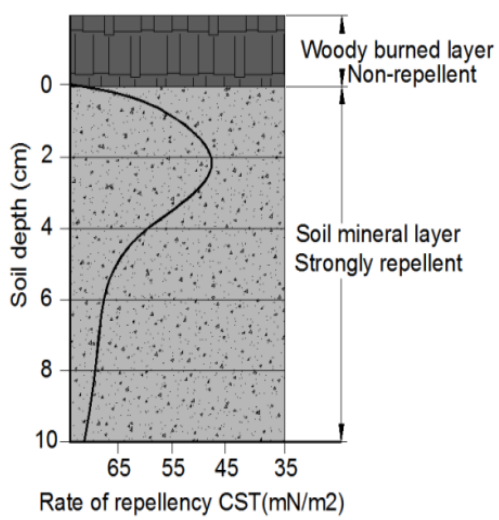

Figure 4. Conceptual cross-section profile illustration of the severely burned soil in the study site. considered; an extremely water repellent soil for the eight $\mathrm{cm}$ top layer (depth of measured water repellent soil) with low hydraulic conductivity $(2 \mathrm{~mm} / \mathrm{h})$ and underneath silt loamy soil with average hydraulic conductivity of $80 \mathrm{~mm} / \mathrm{h}$, based on the average values of both field and laboratory measurements undertaken in the study site.

Table 2. Kineros2 parameters and values for the initial modelling set up.

\begin{tabular}{|l|c|c|c|l|}
\hline Parameter & Symbol & Units & Range & Source \\
\hline Saturated hydraulic conductivity & $\mathrm{K}_{\text {sat }}$ & $\mathrm{mm} / \mathrm{h}$ & 2 & An average value subtracted from rainfall-runoff data \\
Effective net capillary drive & $\mathrm{G}$ & $\mathrm{mm}$ & 2 & No special variability for $\mathrm{K}_{\text {sat }}$ during simulations \\
\hline Variation of $\mathrm{K}_{\text {sat }}$ & $\mathrm{CV}$ & -- & 0 & Excluding the effects of soil spatial variability \\
Soil layer thickness & $\mathrm{Th}$ & $\mathrm{mm}$ & 80 & Field observation \\
\hline Initial Saturation & $\mathrm{sat}$ & -- & $0.1-0.04$ & Oven dried analysis for GWC $(10 \%-4 \%)$ \\
Pore size distribution index (DIST) & $\lambda$ & & 0.15 & Laboratory measurement (varied in range of $0.15-0.65)$ \\
Porosity & $\theta$ & -- & 0.35 & Laboratory analysis(varied in range of $0.25-0.35)$ \\
Rock & $\mathrm{Ro}$ & & 0 & Laboratory measurement $(<0.46 \%)$ \\
Slope factor & $\mathrm{sl}$ & $\mathrm{degree}$ & 27 & Field observation \\
Interception depth & $\mathrm{i}$ & & 2 & Water storage capacity in burned layer () \\
Canopy coverage & $\mathrm{p}$ & & 1 & $100 \%$ coverage of woody burned layer \\
\hline Manning's coefficient & $\mathrm{n}$ & $\mathrm{sm}-1 / 3$ & 0.085 & Based on particle size (d50\%=50 mm, d90\%=40 $\mathrm{mm})$ \\
Relief (microtopography) & $\mathrm{re}$ & $\mathrm{mm}$ & 3 & Field observation \\
Relief spacing & $\mathrm{rs}$ & $\mathrm{m}$ & 0.05 & Field observation \\
\hline
\end{tabular}

Field observation showed that the surface condition in the dry eucalyptus forest did not change considerably during the first year following fire. Therefore a single Manning's value was appointed as a valid effective hydraulic roughness. Only soil particle size as resistance factor on the flow bed (D50 and D90) was considered for primary estimation of overland flow effective friction factor (Manning's n).

Other soil-surface parameters were taken either from field and laboratory measurements or previous studies in burned dry eucalyptus forest as presented in Table 2 . These parameters were used in primary rainfallrunoff model setup (Figure 4) and one simulation operated per each event.

\subsection{Calibration}

To reduce errors associated with over-parameterization, parameters for calibration were categorized in two groups and automated stepwise approach was operated for each group separately. First, parameters that were presumed to have higher influential rule in soil infiltration and transport consisting of hydraulic conductivity 
$\left(\mathrm{K}_{\text {sat }}, 1-15 \mathrm{~mm} / \mathrm{h}\right.$ ), effective net capillary drive (G, 0-20 mm), and hydraulic roughness (Manning's $\mathrm{n}, 0.01$ $\left.0.9 \mathrm{sm}^{-1 / 3}\right)$ were calibrated together. Variant soil hydraulic properties $\left(\mathrm{K}_{\text {sat }}\right)$ were appointed for the study period to display retainment and breakage of soil water repellency. Optimum calibrated values were assigned for these parameters in the next round of calibration.

The second round of calibration was designed with new set of combinations of soil hydraulic properties consisting of porosity $(\phi)$ in range of $0.25-0.35$ from laboratory analysis, pore size distribution index $(\lambda)$ in range of $0.15-0.65$ from soil texture class and initial water content in range of (15\%-3\%), approximated within upper and lower limits of obtained values of gravimetric water content (GWC) from six soil sample groups taken during one year.

Model performance was validated by Nash-Sutcliffe (1970) statistical metric to compute coefficient efficiency of both peak and total volumes (Goodrich et al., 2012) between simulated and observed results from both runoff plots one at a time.

\section{RESULTS}

Results from the initial simulations showed that except simulations for event 14, the simulated hydrographs obtained a very poor Nash-Sutcliffe (ME $<-1)$. Peak and mean values of simulated hydrographs were highly overestimated. There were lower rates of errors in total volume of simulated discharge.

In the first round of calibration, the optimum values of parameters were chosen by accepting runs with NashSutcliffe (ME) $>0.25$ and total volume error indicator $<25 \%$. Accepted results in relation to performance indicators showed that both peak and mean errors of simulated hydrographs were sensitive to Manning's $n$ values. Thus, further refinements were taken by setting boundaries for peak and mean, and readjusting ME and total volume of accepted runs.

From the range of calibrated Manning's $n$ of the accepted runs in all fourteen events, the value of 0.64 was appointed, seven times higher than initial value. This was expected for the reason that only bed particle size was accounted in the initial model setup and other resistance factors were excluded in efficient hydraulic roughness calculation. Similar trend of multiplied Manning's n value was encountered in Chen et al. (2013), investigating efficiency of different models including Kineros2 for rainfall-runoff modelling in fire affected watersheds. In Chen et al. (2013), the primary Manning's value; ranged 0.015-0.055, increased by the factor of five after calibration and resulted in closer fits for simulated runoff peaks and also slight improvements in total runoff volumes.

On the contrary to hydraulic roughness, inconstant saturated hydraulic conductivity $\left(\mathrm{K}_{\text {sat }}, \mathrm{mm} / \mathrm{h}\right)$ was obtained from calibration; parameterized by factors of one to five. Parameterized values of $\mathrm{K}_{\text {sat }}$ were compared to laboratory measurements of soil water repellency and also compared with the previous studies in post-fire water repellent soil of arid and semi-arid forest (Nyman et al., 2010; 2014; Moody\& Ebel, 2014).

A constant value of $2.00 \mathrm{~mm}$ was considered for effective net capillary drive parameter $(\mathrm{G})$ for the reason that spatially-variable soil properties were excluded in this study. All accepted simulated hydrographs obtained this value in their range values of the calibrated parameter. A single effective value for G, also recommended in Guber et al. (2014) that studied root of uncertainties, specifically associated with effective net capillary drive $(\mathrm{G})$ in Parlange equation with exclusion of spatial variability of hydraulic properties.

From the second round of calibration, optimum values of 0.34 and 0.25 were accepted for porosity and pore index parameters. A whole range of appointed water content values from 15 to 3 were found in the accepted runs, thus appointed values of this parameter for each event was retained in the same trend of previous values (10-3), equal to measured GWC values of field soil samples taken in the approximate date that storms had occurred. Parameterizations of the second calibration group resulted in slight deviations $(<5 \%)$ of performance indicators of accepted runs indicating less sensitivity of hydrographs dynamics to variations of the second groups of soil hydraulic properties.

\section{DISCUSSION AND CONCLUSION}

Despite the fact that traditional infiltration theories are not fully applicable to strongly hydrophobic soil in the study area, soil infiltration model was well-adjusted and successfully simulated dominant factors in controlling vertical preferential water movement for the majority of the events as shown in Figure 5 (ME $>$ $50 \%$ and $\mathrm{R}^{2}>0.5$ ). This achievement was gained by adapting soil infiltration concepts and domains to measurements of post-fire hydrophobic conditions in the initial model setup and parametrization. Variant $\mathrm{K}_{\text {sat }}$ was appointed during the year of study period demonstrating both fire-induced restraint and gradual breakage of water repellency. An optimum constant roughness was considered for the same period representing very slow recovery of surface vegetation in dry eucalyptus forest after fire. 
L.P. Kasmaei et al., Modelling overland flow on burned hillslopes using the KINEROS2 model

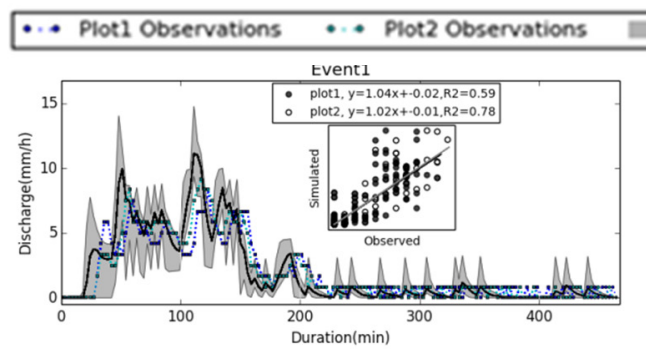

Accepted Hydrographs Band - Optimum hydrograph
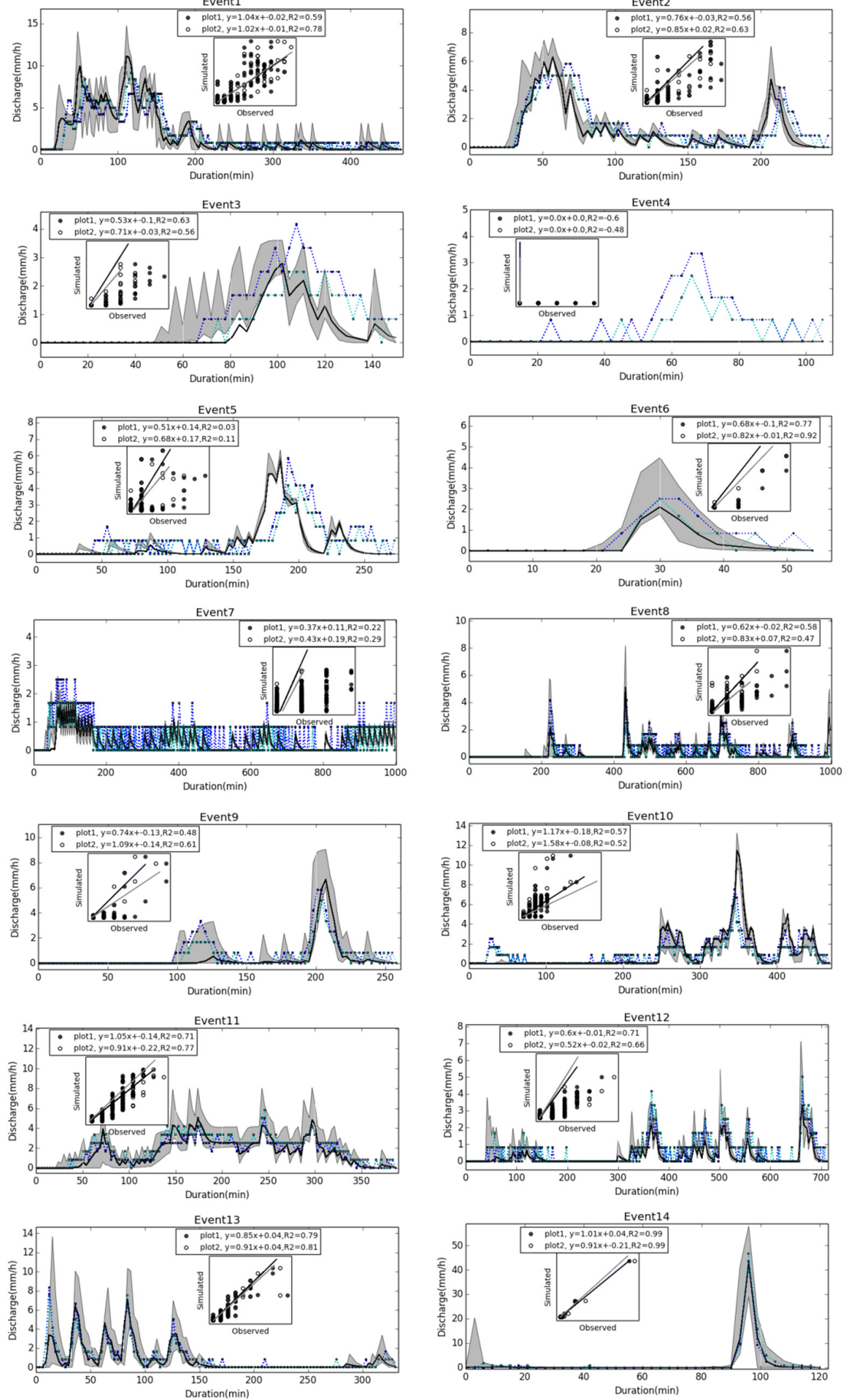

Figure 5. Accepted hydrographs band and optimum values in comparison to observations. 


\section{REFERENCES}

Cawson, J.G., Sheridan, G.J., Smith, H.G., and Lane, P.N.J. (2012). Surface runoff and erosion after prescribed burning and the effect of different fire regimes in forests and shrublands: a review. International Journal of Wildland Fire, 16pp.

Chen, L., Berli, M., Chief. K. (2013). Examining modelling approaches for the rainfall-runoff process in wildfire-affected watersheds: using San Dimas experimental forest. The American Water Resources Association 49(4), 851-866.

Doerr, S.H., Shakesby, R.A., MacDonald, L.H. (2009). Soil water repellency: A key factor in post-fire erosion. In: Cerdà, A., Robichaud, P.R. (Eds.), Fire effects on soils and restoration strategies. Science Publishers, New Hampshire, Enfield, NH, 197-223.

Goodrich, D.C., Burns, I.S., Unkrich, C. L., Semmens, D. J., Guertin, D. P., Hernandez, M., Yatheendradas, S., Kennedy, J. R., Levick, L. R. (2012). KINEROS2/AGWA: Model use, calibration, and validation. ISSN 2151-0032. American Society of Agricultural and Biological Engineers 55(4). 1561-1574.

Guber, A. K., Y. A. Pachepsky, A. M. Yakirevich, D. R. Shelton, A. M. Sadeghi, D. C. Goodrich, and C. L. Unkrich. 2011. Uncertainty in modelling of faecal coliform overland transport associated with manure application in Maryland. Hydrological Process. 25(15): 2393-2404.

Lane, P.N.J., Sheridan, G.J., Noske, P.J., Sherwin, C.B., Costenaro, J.L., Nyman, P., Smith, H.G. (2012). Fire effects on forest hydrology: lessons from a multi-scale catchment experiment in SE Australia, IAHS Publication 353, pp. 137-143.

Letey, J., Carrillo, M.L.K., Pang, X.P. (2000). Approaches to characterize the degree of water repellency. Journal of Hydrology 231-232, 61-65.

Moody, J.A., Shakesby, R. A., Robichaud, P.R., Cannon, S.H., Martin, D.A. (2013). Current research issues related to post-wildfire runoff and erosion processes. Earth-Science Reviews 122, 10-37.

Nash, J. E., Sutcliffe, J. V. (1970). River flow forecasting through conceptual models: I. A discussion of principles. Journal of hydrology 10(3), 228-290.

Nyman, P., Sheridan, G.J., Smith, H.G., Lane, P.N.J. (2010). Synergistic effects of water repellency and macropore flow on the hydraulic conductivity of a burned forest soil, southeast Australia. Hydrological Processes 24 (20), 2871-2887.

Nyman, P., Sheridan, G.J., Smith, H.G., Lane, P.N.J. (2014). Modeling the effects of surface storage, macropore flow and water repellency on infiltration after wildfire Journal of Hydrology 513, 301-313.

Sheridan, G.J., Lane, P.N.J., Noske, P.J. (2007). Quantification of hillslope runoff and erosion processes before and after wildfire in a wet Eucalyptus forest. Journal of Hydrology 343, 12- 28.

Smith, R.E., D.C. Goodrich, D.A. Woolhiser, and C.L. Unkrich, 2005. KINEROS - A Kinematic Runoff and Erosion Model. In: Computer Models of Watershed Hydrology, V.J. Singh (Editor). Water Resources Publications, Highlands Ranch, Colorado, pp. 597-632.

Smith, H.G., Sheridan, G.J., Lane, P.N.J., Nymana, P., Haydon, S., (2011). Wildfire effects on water quality in forest catchments: A review with implications for water supply. Journal of Hydrology 396 (2), 170-192.

Stoof, C. R., Vervoort, R. W., Iwema, J., van den Elsen, E., Ferreira, A. J. D. and Ritsema, C. J. (2012). Hydrological response of a small catchment burned by experimental fire. HESS 16: 267-285.

Onda Y., Dietrich W.E., Booker F. (2008). Evolution of overland flow after a severe forest fire, Point Reyes, California. Catena. 72, 13-20.

Parlange, J. Y., Lisle, I., Braddock, R. D., Smith, R. E. (1982). The three-parameter infiltration equation. Soil Science 133(6), 337-341.

Rawls, W.J., Brakensiek, D.L., Saxton, K.E. (1982). Estimation of soil water properties. Trans. ASAE 25:1316-1320. 